\title{
CD28 Costimulation of T Helper 1 Cells Enhances Cytokine Release In Vivo
}

\begin{abstract}
Daniela Langenhorst ${ }^{1}$, Stephanie Haack ${ }^{1}$, Selina Göb ${ }^{1}$, Anna Uri' ${ }^{1}$, Fred Lühder ${ }^{2}$, Bernard Vanhove ${ }^{3,4,5}$, Thomas Hünig ${ }^{1}$ and Niklas Beyersdorf ${ }^{1 *}$
\end{abstract}

${ }^{1}$ Institute for Virology and Immunobiology, University of Würzburg, Würzburg, Germany, ${ }^{2}$ Institute for Multiple Sclerosis Research and Neuroimmunology, University Medical Centre Göttingen, Göttingen, Germany, ${ }^{3}$ Centre de Recherche en Transplantation et Immunologie UMR 1064, INSERM, Université de Nantes, Nantes, France, ${ }^{4}$ Institut de Transplantation Urologie Néphrologie (ITUN), CHU Nantes, Nantes, France, ${ }^{5}$ OSE Immunotherapeutics S.A., Nantes, France

Compared to naive $T$ cells, differentiated $T$ cells are thought to be less dependent on CD28 costimulation for full activation. To revisit the role of CD28 costimulation in mouse T cell recall responses, we adoptively transferred in vitro generated OT-II T helper (Th) 1 cells into C57BL/6 mice (Thy1.2+) and then either blocked CD28-ligand interactions with Fab fragments of the anti-CD28 monoclonal antibody (mAb) E18 or deleted CD28 expression using inducible CD28 knock-out OT-II mice as T cell donors. After injection of ovalbumin protein in adjuvant into the recipient mice we observed that systemic interferon (IFN) $\gamma$ release strongly depended on CD28 costimulation of the Th1 cells, while secondary clonal expansion was not reduced in the absence of CD28 costimulation. For human memory $\mathrm{CD}_{4}{ }^{+} \mathrm{T}$ cell responses we also noted that cytokine release was reduced upon inhibition of CD28 costimulation. Together, our data highlight the so far underestimated role of CD28 costimulation for the reactivation of fully differentiated CD4+ T cells.

Keywords: $\mathrm{CD}^{+}{ }^{+} \mathrm{T}$ helper cells, $\mathrm{T}$ helper 1 cells, antigenic recall, CD28 costimulation, cytokine secretion, mouse, human

\section{INTRODUCTION}

For full activation, naive $\mathrm{T}$ cells require at least two signals: signal one originating from the interaction of the T cell receptor (TCR) with peptide/major histocompatibility complexes and the second signal stemming from the interaction of CD28 with its ligands CD86 and CD80 on antigen-presenting cells (APCs) (1). While the role of $\mathrm{CD} 28$ costimulation for naive $\mathrm{T}$ cell activation and $\mathrm{CD}^{+} \mathrm{Foxp}^{+}$ regulatory $\mathrm{T}$ cell homeostasis and function is very well established (1) less is known about its impact on secondary responses of $\mathrm{CD} 4^{+} \mathrm{T}$ helper (Th) cells. In fact, early experimental evidence indicated that memory $\mathrm{T}$ cells might be less dependent on CD28 costimulation than naive T cells (2). A study following up on the requirement of memory $\mathrm{CD} 4^{+} \mathrm{T}$ cells for $\mathrm{CD} 28$ costimulation in vivo using a mixed population of memory T cells containing about $25 \%$ interferon $\gamma(\text { IFN } \gamma)^{+}$T helper 1 (Th1) cells came to the opposite conclusion (3). However, in this study CTLA-4-Ig was used to block

Abbreviations: APC, antigen-presenting cell; CFSE, carboxyfluorescein succinimidyl ester diacetate; GAPDH, glyceraldehyde3-hosphate dehydrogenase; iCD28ko, inducible CD28 knock-out; IFN $\gamma$, interferon $\gamma$; IL, interleukin; mAb, monoclonal antibody; MFI, median fluorescence intensity; MHC, major histocompatibility complex; OVA, ovalbumin; PBMC, peripheral blood mononuclear cells; PPD, purified protein derivative; Td, tetanus and diphtheria toxoid; Th1 cells, $\mathrm{CD} 4^{+} \mathrm{T}$ helper 1 cells. 
interactions of CD28 with its ligands. Binding of CTLA-4-Ig to the T cells, which express CD86 and CD80 themselves (4), and induction of indoleamine 2,3-dioxygenase (IDO) expression in APCs (5) hamper the interpretation of these data. Another recent and elegant study addressed the role of CD28 in effector/ memory $\mathrm{CD} 4{ }^{+} \mathrm{T}$ cell responses by using OX40-Cre floxed CD28 mice leading to $\mathrm{CD} 28$ deletion after initial antigen recognition, i.e., within the first $48 \mathrm{~h}$ of the primary immune response in vivo (6). Under these conditions, CD28 costimulation was not only required for Th1 cell expansion, but also for the differentiation and maintenance of $\mathrm{T}$ follicular helper cells (6). OX40-Creinduced CD28 deletion does, however, not fully reflect the situation in humans in whom memory $\mathrm{CD} 4^{+} \mathrm{T}$ cell responses are often triggered years after the first vaccination or first encountered with pathogen-derived antigens. Therefore, we set up our study to analyze the contribution of CD28 costimulation during antigenic recall responses of already differentiated mouse Th1 cells. To this end, we first differentiated ovalbumin (OVA) peptide-specific TCR-transgenic OT-II T cells into Th1 cells in vitro before adoptive transfer in vivo and induction of genetic deletion of CD28 or antibody-mediated blocking of the interaction of CD28 with its ligands. As both mouse and human polarized CD4 ${ }^{+}$Th cells have been shown to undergo reprogramming under certain conditions in vitro and in vivo (7-9), we also followed the impact of CD28 costimulation on Th cell lineage stability.

In humans, selective inhibitors of CD28-ligand interactions, i.e., Fab fragments of the anti-CD28 monoclonal antibody $(\mathrm{mAb}) \mathrm{CD} 28.3$, allow to interrogate the contribution of CD28 costimulation to human memory $\mathrm{T}$ cell responses. Blockade of CD28 costimulation with the CD28.3-Fab-derived drug FR104 on a mixed population of $\mathrm{CD}^{+}$and $\mathrm{CD} 8^{+}$human memory $\left(\mathrm{CD}^{2} \mathrm{RA}^{-} \mathrm{CCR7}^{-}\right) \mathrm{T}$ cells has revealed that both alloantigen- as well as virus peptide-driven proliferation of memory $\mathrm{T}$ cells is enhanced by CD28 costimulation $(10,11)$. As our data obtained with mouse OT-II T cells indicated that CD28 costimulation enhanced IFN $\gamma$ secretion by restimulated Th1 cells, we also studied cytokine secretion by human peripheral blood mononuclear cells (PBMC) upon addition of $\mathrm{T}$ cell recall antigens in vitro. As for the mouse T cells, CD28 costimulation of human T cells, too, increased cytokine secretion upon antigenic recall.

\section{MATERIALS AND METHODS}

\section{Mice}

C57BL/6J.Thy1.1+/- (12), C57BL/6J.OT-II Thy1.1 $1^{+/+}$, C57BL/6J. OT-II Thy1.1 $1^{+/+} \mathrm{ERCre}^{+/-} \mathrm{CD} 28^{\text {flox/flox }}$ inducible CD28 knockout mice and their C57BL/6J.OT-II Thy1.1 ${ }^{+/+} \mathrm{ERCre}^{+/-} \mathrm{CD} 28^{\mathrm{wt} / \mathrm{wt}} \mathrm{WT}$ littermates were bred and maintained in the specific pathogen-free animal facility of the Institute for Virology and Immunobiology at the University of Würzburg. To obtain these mouse strains, we used C57BL/6J.OT-II (13) and C57BL/6J.ERCre ${ }^{+-}$CD28 $8^{\text {flox/flox }}$ inducible CD28 knock-out mice $(14,15)$ for crossings. Animals used for experiments were between 6 and 15 weeks old.

\section{Peripheral Blood Mononuclear Cells}

Human PBMCs were prepared from healthy blood donors as a byproduct of platelet concentrates obtained with leukoreduction system chambers [LRS-C; Gambro Trima Accel aphaeresis apparatus, Pall Corp. (16)], diluted in versene, isolated by density gradient centrifugation with Lymphocyte Separation Medium (PAA Laboratories), and washed with ice-cold balanced salt solution (BSS)/0.2\% BSA. The leukoreduction chambers were provided anonymously by the Department of Transfusion Medicine of the University Hospital Würzburg in accordance with the guidelines of the Ethics Committee of the Medical Faculty of the University of Würzburg.

\section{Generation of Th1 Cells and In Vitro Conversion (Mouse)}

Naïve MACS-sorted CD4 ${ }^{+}$CD25- OT-II T cells from spleen and lymph nodes were cultured in RPMI 1640 with L-glutamine, nonessential amino acids, $\beta$-mercaptoethanol, sodium pyruvate, penicillin/streptomycin, and 10\% FCS (all Gibco) in the presence of Thy1.2 (T cell)-depleted APCs and $2 \mu \mathrm{M} \mathrm{OVA}_{327-339}$ (Charité Berlin). For Th1 differentiation $10 \mu \mathrm{g} / \mathrm{ml}$ anti-interleukin (IL)-4 (11B11, Bio X Cell) and $10 \mathrm{ng} / \mathrm{ml} \mathrm{IL-12} \mathrm{(R \& D} \mathrm{Systems)} \mathrm{were}$ added-similar to what has been previously described (8). Cell cultures were split on days 2 and 4 . For in vitro conversion experiments differentiated Th1 cells were washed with BSS/ BSA on day 6 and reactivated with fresh T cell-depleted APCs and, for Th0 conditions, with $0.1 \mu \mathrm{M}$ recombinant human (rh) IL-2 (Proleukin ${ }^{\circledR}$, Novartis); for Th2 conditions-again close to a published protocol (8) - with $10 \mu \mathrm{g} / \mathrm{ml}$ anti-IL-12 (C17.8, Bio X Cell), $10 \mu \mathrm{g} / \mathrm{ml}$ anti-IFNy (XGM1.2, Bio X Cell), $100 \mathrm{ng} / \mathrm{ml}$ recombinant mouse IL-4 (Miltenyi Biotec) and, in addition, $0.1 \mu \mathrm{M}$ rhIL-2 in the presence and absence of $1 \mu \mathrm{M} \mathrm{OVA}_{327-339}$ and $10 \mu \mathrm{g} / \mathrm{ml} \mathrm{Fab}$ fragment of anti-CD28 mAb E18 (Exbio). On days 5 and 10 of the culture we analyzed the cells by FACS.

\section{In Vitro Recall Responses (Human)}

Isolated carboxyfluorescein succinimidyl ester diacetate (CFSE) $(5 \mu \mathrm{M})$ labeled PBMCs were cultured in RPMI 1640 medium supplemented with L-glutamine (Invitrogen), nonessential amino acids (Invitrogen), HEPES (Applichem), $\beta$-mercaptoethanol (Invitrogen), sodium pyruvate (Invitrogen), penicillin/streptomycin, and 10\% heat-inactivated human AB serum (Sigma-Aldrich) in the presence or absence of $0.1 \mu \mathrm{g} / \mathrm{ml}$ anti-CD3 mAb (HIT3a), $10 \mu \mathrm{g} / \mathrm{ml}$ purified protein derivative (PPD) (Pharmore), $100 \mathrm{mU} / \mathrm{ml}$ tetanus and diphtheria toxoid (Td)-RIX (GlaxoSmithKline), and $0.3 \mu \mathrm{g} / \mathrm{ml}$ Fab fragment of the anti-human CD28 mAb CD28.3. To generate Th1 conditions, $1 \mu \mathrm{g} / \mathrm{ml}$ anti-human IL-4 (R\&D Systems), $2 \mathrm{ng} / \mathrm{ml} \mathrm{rhIL}-12$ (Sigma) and, additionally, $0.1 \mu \mathrm{M}$ rhIL-2 (Proleukin ${ }^{\circledR}$, Novartis) were added (7). Th2 conditions consisted of $2 \mu \mathrm{g} / \mathrm{ml}$ anti-human IL-12 (R\&D Systems), $2 \mathrm{ng} / \mathrm{ml}$ rhIL-4 (Miltenyi) and, in addition, $0.1 \mu \mathrm{M}$ rhIL-2 (7). For Th0 conditions, no further cytokines or antibodies were added. After 6 days of culture the cells were analyzed by FACS.

In some experiments (Figure 5), PBMCs were first stained with anti-CD4 (OKT4), CD45RA (HI100), and CCR7 (G043H7) (all BioLegend) and either $\mathrm{CD} 4^{+} \mathrm{CD} 45 \mathrm{RA}^{-}$memory $\mathrm{T}$ cells or $\mathrm{CD}^{+} \mathrm{CD}^{+} 5 \mathrm{RA}^{+} \mathrm{CCR}^{+}$naive $\mathrm{T}$ cells were separated from the PBMC by flow cytometric cell sorting. The sorted PBMCs were then also labeled with CFSE and either stimulated alone or in the presence of the previously separated $\mathrm{CD} 4^{+} \mathrm{T}$ cell subset added 
back before initiation of the cultures. To determine proliferation of CFSE-labeled and unlabeled cells, the cultured PBMCs were stained extracellularly for CD4 and intracellularly for Ki-67 expression (B56, BD) after 4 days of incubation.

\section{In Vivo Recall Responses and CD28 Blockade/Deletion}

$2 \times 10^{6}$ activated, OVA-specific Th1 cells (day 4 in vitro) of OT-II Thy $1.1^{+/+}$, OT-II iCD28ko (OT-II Thy1.1 $1^{+/+} \mathrm{ERCre}^{+/-} \mathrm{CD} 28^{\text {flox } /}$ flox) mice or WT littermates were transferred intravenously into C57BL/6 Thy $1.1^{+/-}$recipients on day 0. $100 \mu \mathrm{g}$ Fab fragment of anti-mouse CD28 mAb E18 (Exbio) or control antibody MOPC-21 (Bio X Cell) were injected i.p. on five consecutive days, starting with the day after T cell transfer. To delete CD28 expression on iCD28ko donor T cells, $1.25 \mathrm{mg}$ tamoxifen (Hexal AG) was administered in watery solution to recipient mice by oral gavage for four consecutive days, beginning with the day after $\mathrm{T}$ cell transfer. Either on day 3 (E18-Fab) or day 9 after $\mathrm{T}$ cell transfer (tamoxifen) we injected $10 \mu \mathrm{g}$ OVA protein (Sigma) in $50 \mu \mathrm{l}$ phosphate-buffered saline (PBS) emulsified in $150 \mu \mathrm{l}$ Alum (Serva) s.c. 6, 24, and $48 \mathrm{~h}$ after antigen administration blood samples were taken from the tail vein and sera were stored at $-80^{\circ} \mathrm{C}$ until analysis. Lymph node and spleen cells were analyzed 7 days after antigen challenge.

\section{Flow Cytometry}

The following antibodies and dyes were used for FACS analysis of human cells: CD4 (RPA-T4), GATA-3 (16E10A23), T-bet (4B10) (all BioLegend), and dead cell marker Viability Dye eFluor ${ }^{\mathrm{TM}}$ 780 (eBioscience). The following antibodies and dyes were used for FACS analysis of mouse cells: CD4 (RM4-5), Thy1.1 (Ox-7), Thy1.2 (30-H12), Gata-3 (16E10A23), IL-4 (11B11), IFN $\gamma$ (XGM1.2), T-bet (eBio4B10) (all BioLegend), and dead cell marker Viability Dye eFluor ${ }^{\mathrm{TM}} 780$ (eBioscience). For intracellular cytokine analysis, cells were restimulated with $5 \mathrm{ng} / \mathrm{ml}$ PMA and $500 \mathrm{ng} / \mathrm{ml}$ ionomycin for $4 \mathrm{~h} .10 \mu \mathrm{g} / \mathrm{ml}$ BrefA were added after $2 \mathrm{~h}$. Stainings were performed with up to $10^{6}$ cells from PBMC, lymph node, or erythrocyte depleted spleen cells, in $50 \mu \mathrm{l}$ of FACS buffer (PBS/0.1\% bovine serum albumin/0.02\% $\left.\mathrm{NaN}_{3}\right)$. After surface staining $\left(30 \mathrm{~min}, 4^{\circ} \mathrm{C}\right)$, cells were fixed for $30 \mathrm{~min}$ at $4^{\circ} \mathrm{C}$ (fixation buffer, eBioscience), permeabilized (permeabilization buffer, eBioscience), and intracellularly stained for Gata-3 and T-bet or IL-4 and IFN $\gamma$ expression for $45 \mathrm{~min}$ at room temperature. The cells were analyzed on a $\mathrm{BD}^{\mathrm{TM}} \mathrm{LSR}$ II flow cytometer with the use of FACS Diva software (all Becton Dickinson). For further analyses of the data, FlowJo (TreeStar Inc.) software was used. Median fluorescence intensity (MFI) ratios of T-bet and Gata- 3 were calculated by dividing the median fluorescence intensities of the two markers.

\section{Analysis of Cytokine Concentrations in Serum and Culture Supernatant}

Cytokine concentrations in serum and culture supernatant (mouse and human) were analyzed using the LEGENDplex beadbased immunoassay (BioLegend) according to the manufacturer's instructions.

\section{Statistical Analysis}

Data are presented as mean + SD or median + range as indicated. Statistical significance was analyzed by two-tailed unpaired $t$-test, one-tailed paired $t$-test, or Mann-Whitney $U$ test using GraphPad Prism Software. Values of $p<0.05$ were considered to be statistically significant.

\section{Ethics Statement}

All animal experiments were performed in accordance with German law and approved by the Regierung von Unterfranken as the responsible authority. The ethics committee of the medical faculty of the University of Würzburg approved the anonymous use of human PBMC from healthy blood donors for this study.

\section{RESULTS}

\section{IFN $\gamma$ Release Upon Antigenic Challenge of Th1 Cells In Vivo Requires CD28 Costimulation}

In order to study the contribution of CD28 costimulation to Th1 recall responses, we first differentiated naive OT-II Thy1.1 $1^{+}$TCRtransgenic $\mathrm{CD} 4^{+} \mathrm{T}$ cells into Th1 cells in vitro before transferring them into C57BL/6 recipient mice (Thy1.2+) (Figures 1A,B). We then either blocked CD28-B7 ligand interactions with Fab fragments of mAb E18 $(17,18)$ or induced CD28 deletion by tamoxifen treatment of the recipient mice (Figures 1A,B). Afterward, we challenged the recipient mice with OVA/Alum and followed cytokine release in the serum for up to $48 \mathrm{~h}$ after the challenge (Figure 1C). Antigen challenge induced systemic IFN $\gamma$ release into the circulation in mice which had received Th1 OT-II T cells (Figure 1C). Blocking CD28-B7 ligand interactions (Figure 1C, left graphs) or tamoxifen-induced CD28 deletion (Figure 1C, right graphs), however, clearly diminished IFN $\gamma$ concentrations in the serum. This observation is in line with the known enhanced IFN $\gamma$ expression during primary effector $\mathrm{T}$ cell responses after release of IFN $\gamma$ mRNA from glyceraldehyde-3-hosphate dehydrogenase (GAPDH) upon induction of glycolysis (19), which itself is driven by CD28 costimulation (20). The reduction in IFN $\gamma$ release was not accompanied by an induction of systemic IL-5 release, suggesting that there was no actual reprogramming of the Th1 cells toward a Th2 phenotype (8) (Figure 1C). Reduced overall cytokine release may be due to reduced secondary clonal expansion of the transferred Th1 cells in the absence of CD28 costimulation. Therefore, we quantified the yield of the progeny of the transferred Th1 cells retrieved 7 days after antigenic challenge in vivo (Figures 2A,B). Seven days post antigenic challenge is well within the phase of secondary (memory) $\mathrm{CD}^{+} \mathrm{T}$ cell expansion which has been shown to last until 30 days post antigenic challenge (21). Unlike to what has been described for naive T cells (1), CD28 costimulation was not critical for secondary clonal expansion of Th1 cells. Without antigenic challenge we were not able to detect any daughter cells of the transferred Th1 cells in the recipient mice ( $n=4$ mice analyzed) highlighting that the size of the OT-II Th1 cell pool at the time of analysis, indeed, reflected secondary clonal expansion. CD28 costimulation, thus, crucially enhanced cytokine release triggered by antigenic recall of Th1 cells in vivo without affecting secondary clonal expansion. 
A

+/- $2 \cdot 10^{6}$ Th1 i.v.

OT-II Thy $1.1^{+/+}$or

+/- OVA +

OT-II iCD28ko/WT Alum s.c.

blood samples
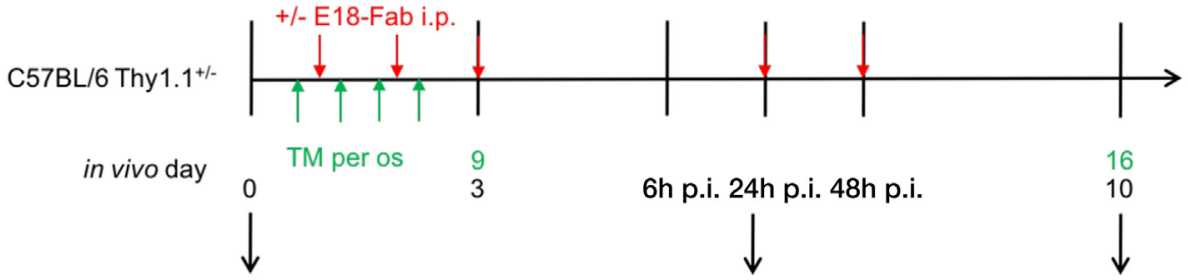

Analysis of Th1 programming $\mathrm{TF}+$ cytokines

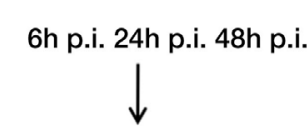

serum cytokine analysis

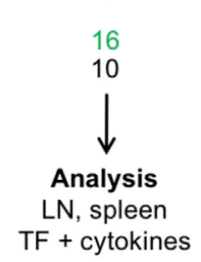

B
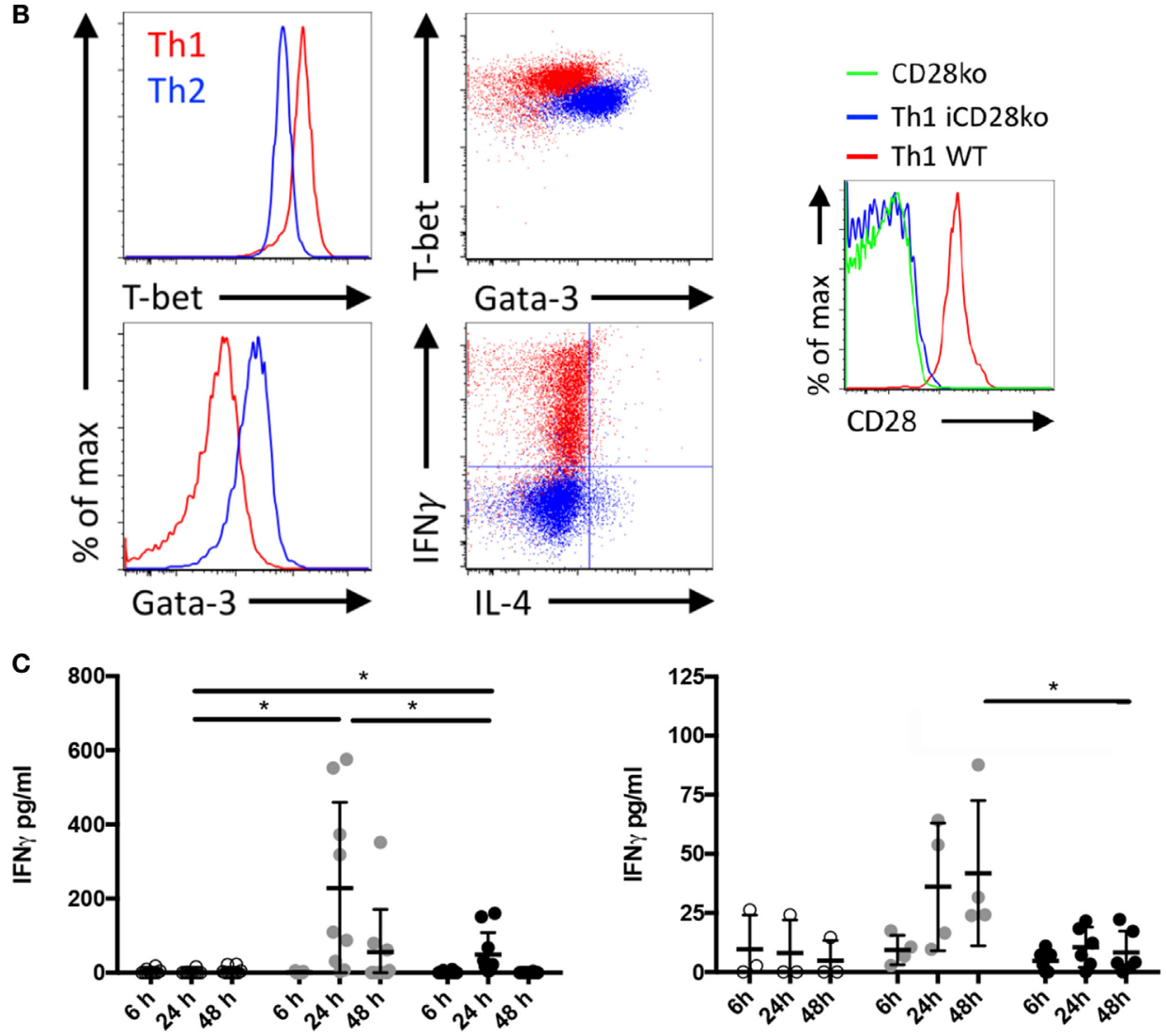

- without Th1 + OVAVAlum

- Th1+ OVAVAlum + control

- Th1+ OVAVAlum + E18Fab

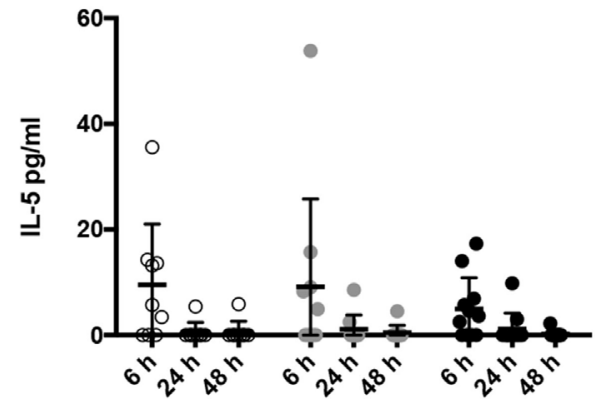

O without Th1 + OVAVAlum

- Th1 WT + OVAVAlum + TM

- Th1 iCD28ko + OVAVAlum + TM

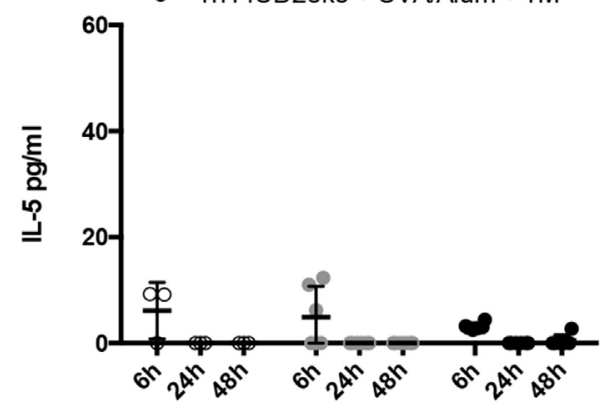

FIGURE 1 | Continued 
FIGURE $1 \mid$ CD28 costimulation of Th1 (T helper 1) cells enhances systemic interferon $\gamma$ (IFN $\gamma$ ) release, but does not modulate Th1 cell expansion in vivo. (A) $2 \times 10^{6}$ in vitro differentiated Th1 cells of OT-II Thy $1.1^{+/+}$mice, OT-II inducible CD28 knock-out (iCD28ko) mice or WT littermates were transferred into Thy $1.1^{1 /-}$ mice. For CD28 blockade, E18-Fab or control was injected on the following 5 days. CD28 deletion was induced by tamoxifen treatment from days 1 to 4 in vivo. 3 days and 9 days after T cell transfer, respectively, recipient mice received ovalbumin/Alum by subcutaneous administration. Serum samples were taken 6 , 24, and $48 \mathrm{~h}$ later. Lymph node and spleen cells were analyzed 7 days after antigen challenge. (B) T-bet, Gata-3, IFN $\gamma$, and interleukin (IL)-4 expression in OT-II Th1 (red) and, for comparison, Th2 cells (blue) after 5 days of differentiation and CD28 expression by OT-II iCD28ko Th1 cells 7 days after transfer (histogram). (C) Serum cytokine concentration of IFN $\gamma$ and IL-5 after E18-Fab-mediated CD28 blockade (left figures) and inducible CD28 deletion (right figures). Data for individual mice are shown together with mean and SD. Results were pooled from three to five independent experiments with a total of 4-10 mice per group and tested with a two-tailed $t$-test $\left({ }^{*} p<0.05\right)$.

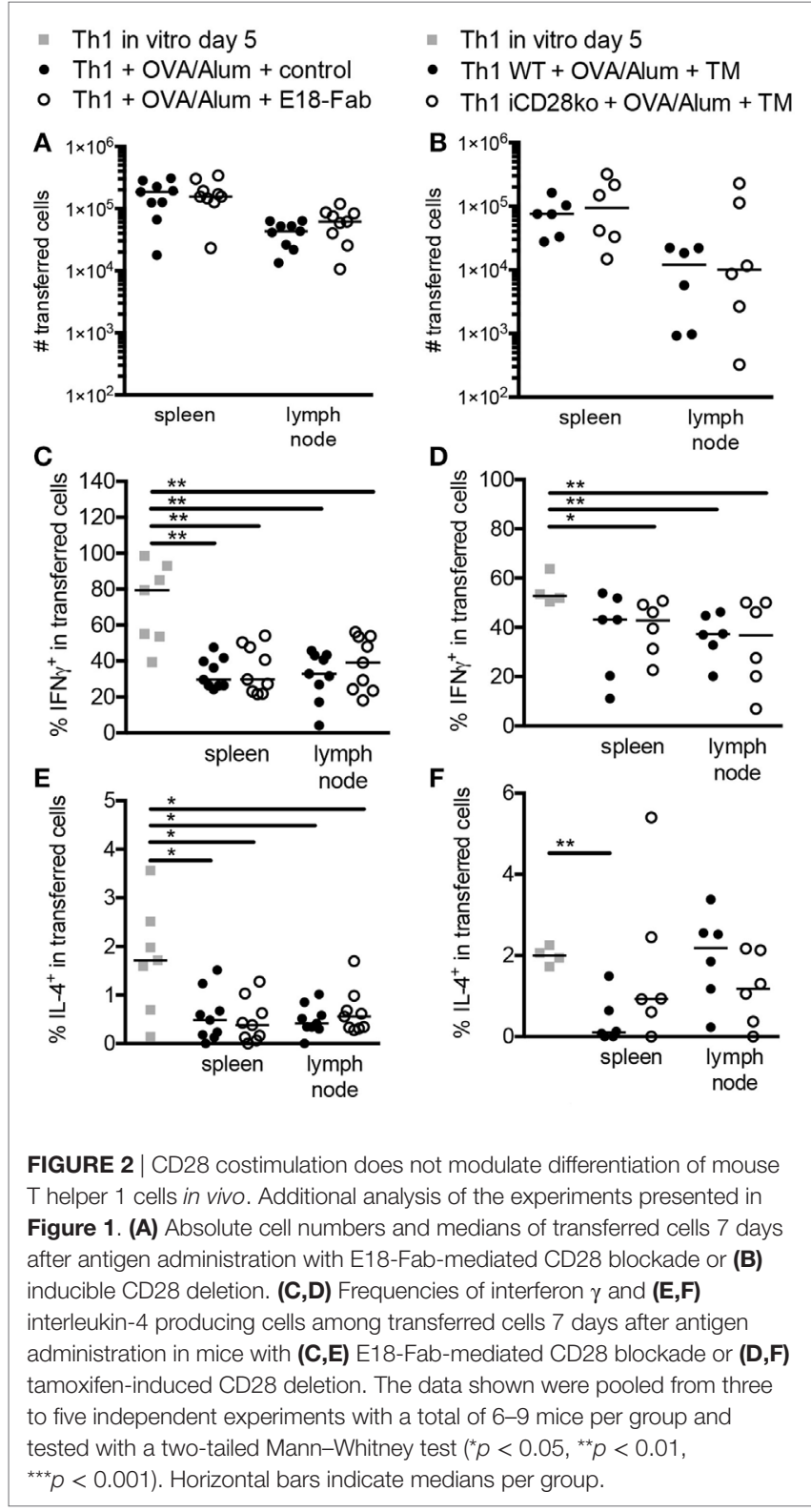

\section{CD28 Costimulation Does Not Modulate Lineage Differentiation of Mouse Th1 Cells In Vivo}

Systemic IL-5 release (Figure 1C, lower panel) lacks sensitivity to be able to truly assess lineage differentiation and reprogramming of
Th1 cells in vivo. We, therefore, re-analyzed IFN $\gamma$ and IL-4 expression by intracellular FACS staining in Th1 cells 7 days after antigen challenge in vivo (Figures 2C-F). Compared to the Th1 cells analyzed at the end of the in vitro differentiation phase, there was a reduction in the frequencies of IFN $\gamma$-producing, and even the few IL-4-producing, cells after in vivo transfer and antigenic challenge. However, neither E18-Fab-mediated abrogation of CD28 signaling (Figures 2C,E) nor tamoxifen-induced CD28 deletion on the donor Th1 cells (Figures 2D,F) had an impact on the frequencies of IFN $\gamma$ and/or IL-4 producers detected among the transferred Th1 cells after PMA/ionomycin restimulation. The data, thus, suggest that, despite clearly modulating systemic IFN $\gamma$ release, CD28 costimulation had no impact on Th1 lineage stability in vivo.

\section{CD28 Costimulation Increases Cytokine Release From Th1 Cells In Vitro}

Deletion of CD28 on the transferred Th1 cells was sufficient to reduce systemic IFN $\gamma$ release in vivo (Figure 1C). The IFN $\gamma$ measured in the serum might, however, in part have stemmed from bystander memory CD8 ${ }^{+} \mathrm{T}$ cells and NK cells fueled by the transferred Th1 cells, presumably through IL-2 secretion, to produce IFN $\gamma$ (22). Therefore, we followed up on our in vivo data with a series of in vitro experiments allowing us to directly measure IFN $\gamma$ release by the Th1 cells themselves, i.e., in the absence of memory $\mathrm{CD}^{+} \mathrm{T}$ cells (Figure 3A). In these in vitro experiments, we first determined the contribution of CD28 costimulation to IFN $\gamma$ secretion by Th1 cells by restimulating them with different concentrations of antigen plus APCs and with or without addition of E18-Fab. IFN $\gamma$ release from differentiated Th1 cells was dependent on CD28 costimulation (Figure 3B, left). After restimulation of the Th1 cells under Th1 conditions, the OT-II Th1 cells secreted very high amounts of IFN $\gamma$ even without addition of antigen, i.e., OVA peptide (Figure 3B, right). IFN $\gamma$ secretion was further enhanced upon addition of OVA peptide $(1 \mu \mathrm{M})$ and even further increased in the presence of E18-Fab (Figure 3B, right). In contrast to restimulation under Th0 conditions (Figure 3B, left), under Th1 conditions CD28 costimulation, thus, did not enhance, but slightly reduced IFN $\gamma$ secretion by Th 1 cells (Figure 3B, right). As the absolute cell numbers of Th1 cells kept under Th 1 conditions were not influenced by CD28 costimulation (data not shown) we could rule out that CD28induced apoptosis of Th1 cells (23) accounted for this observation. IL-5 secretion, which was induced in Th1 cells transferred to Th2 conditions, was also reduced when CD28 costimulation was inhibited (Figure 3C). Taken together, IFN $\gamma$ release from Th1 cells was clearly reduced upon inhibition of CD28-mediated 
A

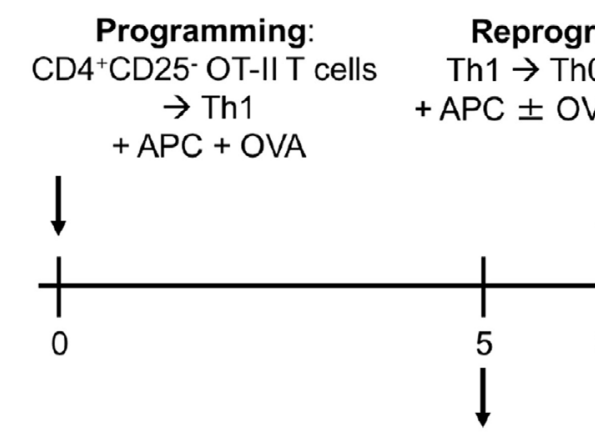

Analysis:

cytokines,

transcription factors

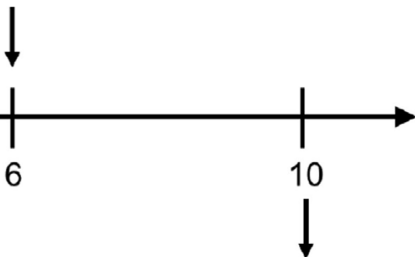

Analysis:

cytokines,

transcription factors
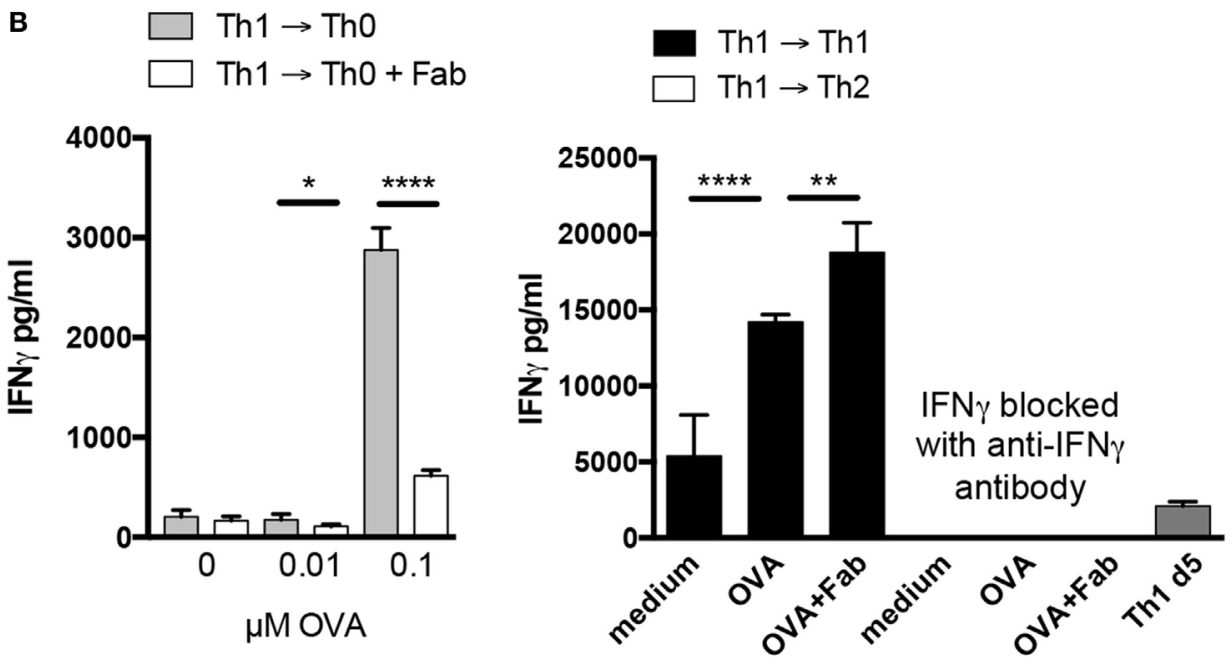

C

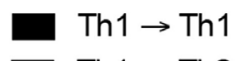

Th1 $\rightarrow$ Th2

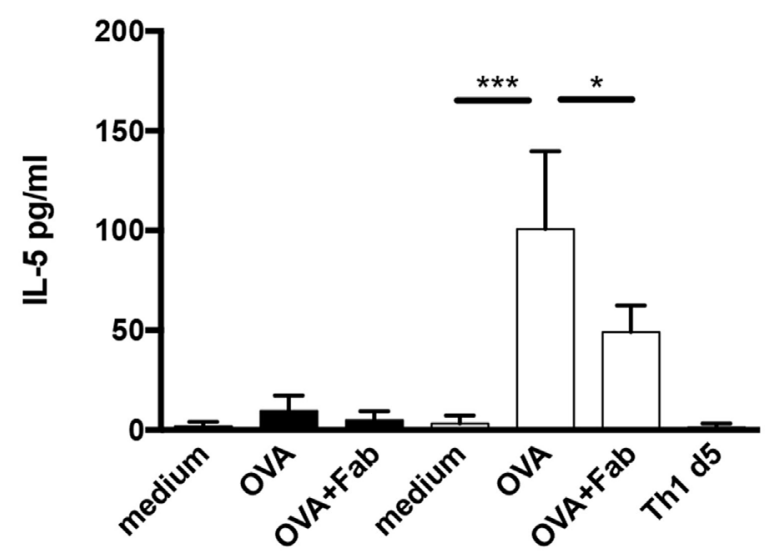

FIGURE 3 | CD28 costimulation increases cytokine release from Thelper 1 cells in vitro. (A) Isolated CD4+CD25- T cells of OT-II Thy 1.1 $1^{+/+}$mice were co-cultured with T cell-depleted splenocytes under Th1 conditions for 6 days and afterward reactivated under Th2, Th0, or Th1 conditions for additional 4 days in the presence and absence of OVA peptide and E18-Fab fragment. (B) Interferon $\gamma$ concentrations in supernatants 4 days after restimulation under ThO (left graph), Th1, or Th2 conditions (both right graph) in the presence or absence of E18-Fab and up to $0.1 \mu \mathrm{M}$ (left) or $1 \mu \mathrm{M}$ ovalbumin (OVA) peptide (right). (C) IL-5 concentrations in supernatants 4 days after restimulation with $1 \mu \mathrm{M}$ OVA peptide under Th1 or Th2 conditions and in the presence or absence of E18-Fab. Graphs show mean + SD of triplicate cultures from one experiment. The results are representative of two to five independent experiments and were tested with a two-tailed unpaired $t$-test $\left({ }^{*} p<0.05,{ }^{* *} p<0.005,{ }^{* * *} p<0.001,{ }^{* * * *} p<0.0001\right)$. 
costimulation in vitro unless the Th1 cells were restimulated under strongly pro-inflammatory Th1 conditions.

\section{CD28 Costimulation Drives Expansion of Human PPD-, but Not Td-Specific Memory T Helper Cells In Vitro}

As our data obtained in mice in vivo and with mouse Th1 cells in vitro showed that $\mathrm{CD} 28$ costimulation enhanced IFN $\gamma$ release by Th1 cells we tested whether in vivo differentiated pathogenspecific human memory $\mathrm{T}$ cells would behave similarly. In mice, we had observed that Th1 cell expansion in vivo was not affected by CD28 costimulation (Figures 2A,B) and also in vitro CD28 costimulation had no effect on the expansion of Th1 cells (data not shown). To test the impact of CD28 costimulation on the expansion of human $\mathrm{CD}^{+}{ }^{+} \mathrm{T}$ cells in vitro under Th0, Th1, and Th2 conditions, we stimulated human PBMC either with an antiCD3 mAb (clone HIT3a), the recall antigen PPD produced by mycobacteria or Td from Clostridium tetani and Corynebacterium diphtheriae. While Td-specific $\mathrm{CD}^{+} \mathrm{T}$ cells comprise both Th1 and Th2 cells (24-26), PPD-specific CD4 ${ }^{+} \mathrm{T}$ cells are predominantly of a Th1 phenotype (27). To inhibit CD28 costimulation we used Fab fragments of the anti-human CD28 mAb CD28.3 (28) at $0.3 \mu \mathrm{g} / \mathrm{ml}$, which we had determined to be optimal to inhibit anti-CD3 mAb-induced proliferation of $\mathrm{CD}^{+} \mathrm{T}$ cells within PBMC (data not shown). To determine the contribution of CD28 costimulation to the expansion of human T cells in the PBMC cultures we analyzed the percentage of CFSE ${ }^{\text {low }}$ cells among $\mathrm{CD}^{+} \mathrm{T}$ cells at the end of the culturing period on day 6 (Figures 4A,B). Blocking CD28 costimulation reduced the yield of CFSE ${ }^{\text {low }}$ cells among CD4 $4^{+} \mathrm{T}$ cells after addition of either antiCD3 mAb (Figure 4B, black columns) or PPD (Figure 4B, light gray columns) independently of the cytokine milieu. In contrast, the expansion of $\mathrm{Td}$-specific $\mathrm{CD} 4^{+} \mathrm{T}$ cells was only modulated by CD28 costimulation under Th2 conditions (Figure 4B, white columns). To verify that the $\mathrm{CD} 4^{+} \mathrm{T}$ cells responding to antigenic recall were, indeed, memory cells we depleted PBMC of either CD45RA ${ }^{-}$memory or $\mathrm{CD}^{-} 5 \mathrm{RA}^{+} \mathrm{CCR}^{+}$naive $\mathrm{CD}^{+} \mathrm{T}$ cells by flow cytometric cell sorting. After depletion of naive $\mathrm{CD}^{+}$ $\mathrm{T}$ cells, recall responses to PPD and Td could still be detected, which was not the case after depletion of memory $\mathrm{CD} 4^{+} \mathrm{T}$ cells (Figures 5A,B). In parallel cultures, we added back the previously depleted cells and then compared cell proliferation by analyzing Ki-67 expression of naive and memory $\mathrm{CD} 4^{+} \mathrm{T}$ cells which were either CFSE-labeled or unlabeled (Figures 5C,D). To ensure that we would be able to clearly detect Ki-67 expression we analyzed all the cultures in Figure 5 already after 4 days instead of 6 . Even in the presence of memory $\mathrm{CD} 4^{+} \mathrm{T}$ cells there was minimal bystander proliferation of naive $\mathrm{CD}^{+} \mathrm{T}$ cells toward recall antigens. Moreover, the memory $\mathrm{CD}^{+} \mathrm{T}$ cells responded well toward PPD and Td stimulation independently of whether they had been labeled with CFSE or not. When naive and memory

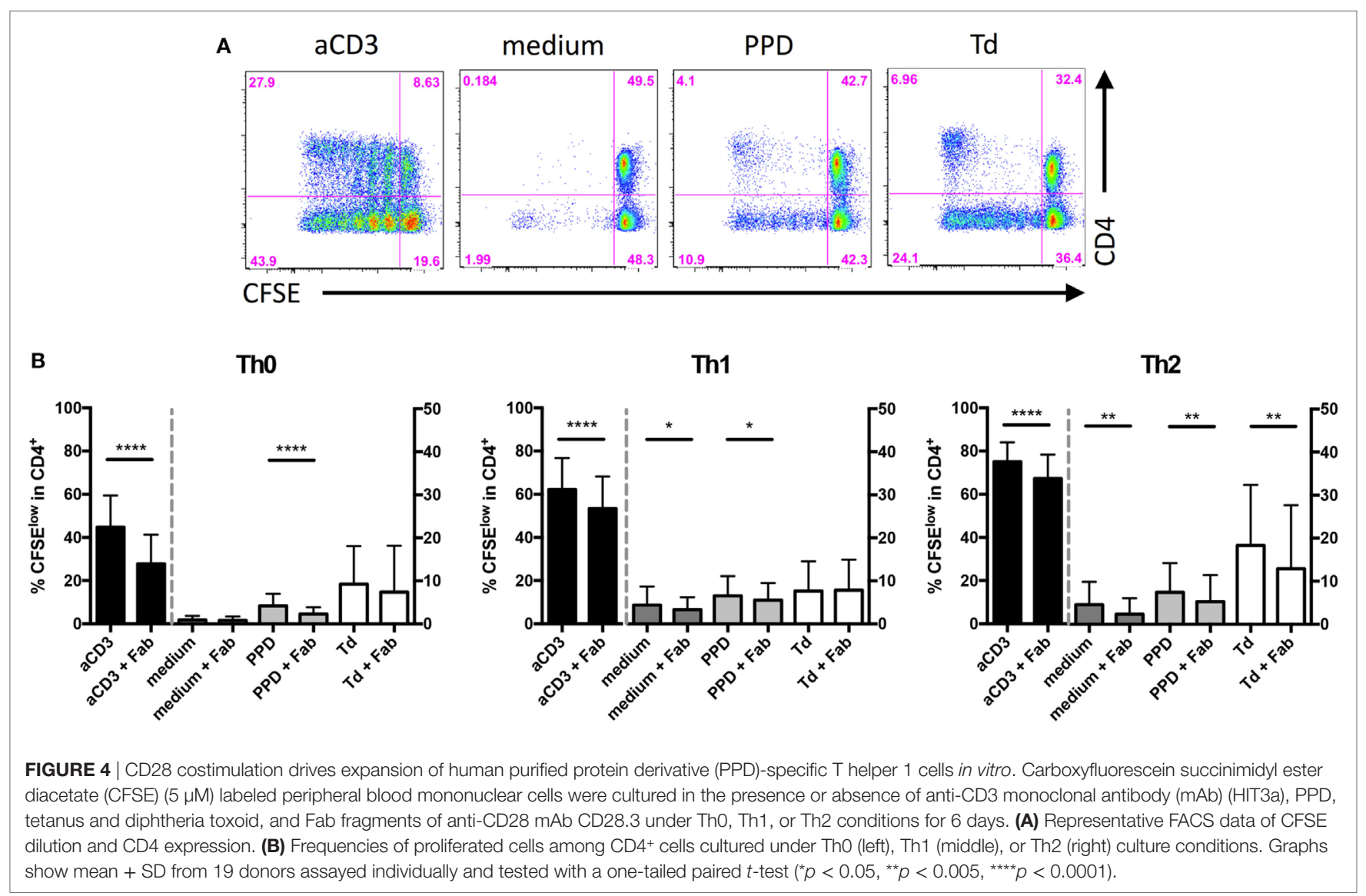



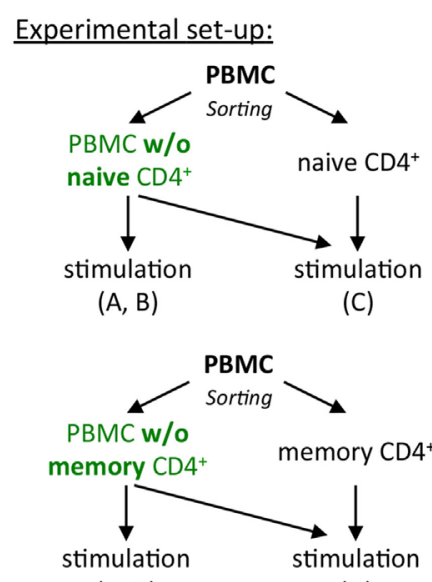

$\begin{array}{ll}(A, B) & \text { (D) }\end{array}$

B

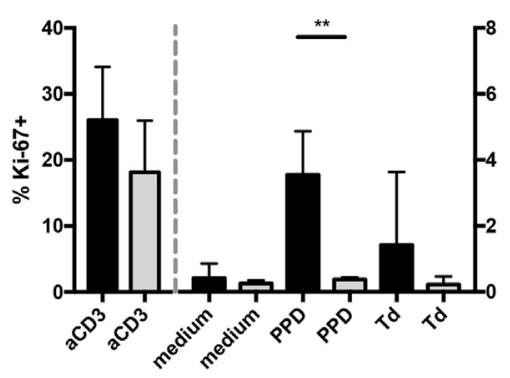

$\mathrm{CD}^{+}{ }^{+}$without naive cells

$\mathrm{CD}^{+}$without memory cells
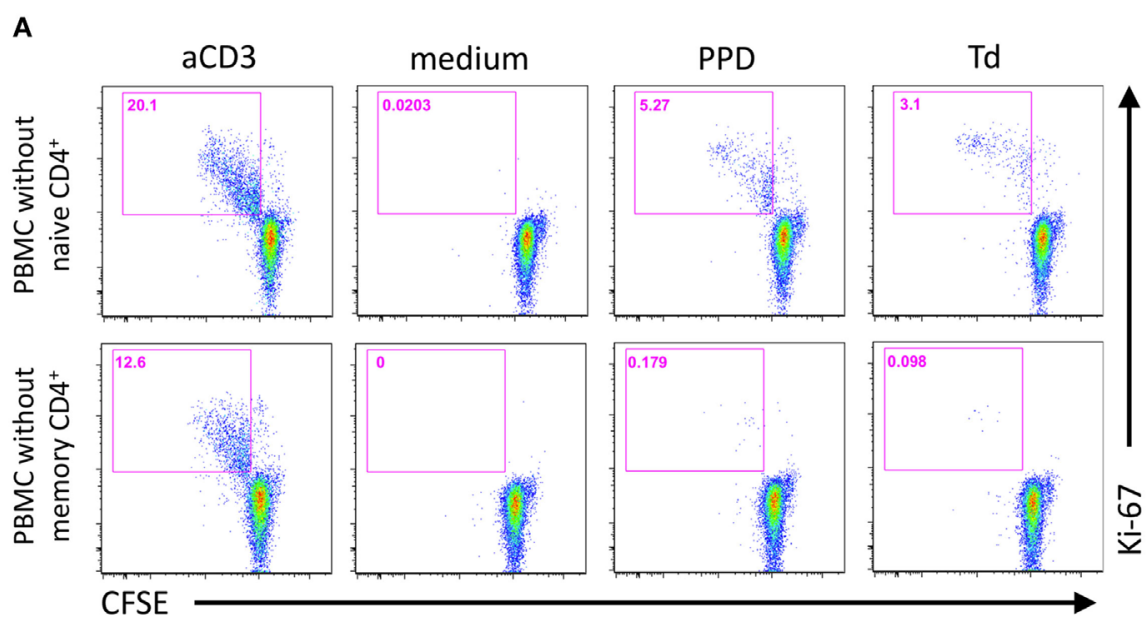

C

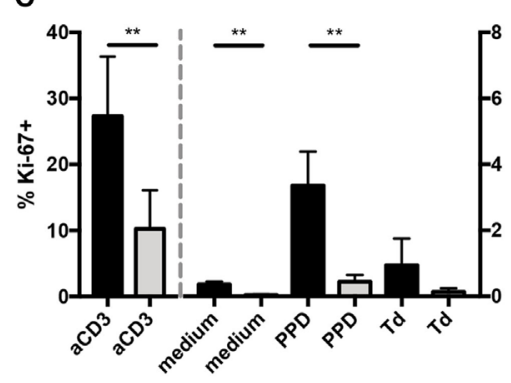

D

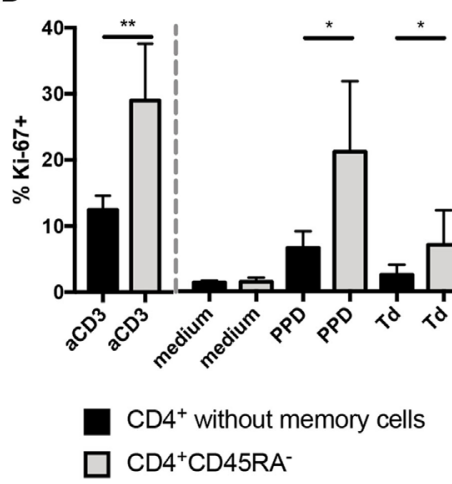

FIGURE 5 | Stimulation of human peripheral blood mononuclear cells (PBMC) with purified protein derivative or tetanus and diphtheria toxoid induces proliferation of memory CD4+ T cells in vitro. PBMC were depleted of naive or memory CD4+ T cells by flow cytometric cell sorting and labeled with carboxyfluorescein succinimidyl ester diacetate (CFSE). As summarized in the scheme, the CFSE-labeled PBMC were then either stimulated alone or with addition of (unlabeled) naive or memory CD4+ $\mathrm{T}$ cells. (A) CFSE dilution among memory (upper row) or naive CD4+ $\mathrm{T}$ cells (lower row) and Ki-67 expression were analyzed after 4 days of culture in the presence of the indicated stimuli. (B) Summary graph of experiments set up as in (A) showing frequencies of $\mathrm{Ki}-67^{+}$cells among $\mathrm{CD} 4^{+} \mathrm{T}$ cells from three independent experiments with cells from one donor each. (C) Frequencies of Ki-67+ cells among CD4+ $\mathrm{CD} 45 \mathrm{RA}{ }^{+} \mathrm{CCR} 7^{+}$naive $\mathrm{T}$ cells (gray columns) added back to naive CD4+ $\mathrm{T}$ cell-depleted PBMC (black columns: \% Ki-67+/memory CD4+ $\mathrm{T}$ cells). (D) Reverse experiment of (C), i.e., frequencies of Ki-67+ cells among CD4+ CD45RA- memory T cells (gray columns) added back to memory CD4+ T cell-depleted PBMC (black columns: \% Ki-67+/naive CD4+ T cells). Columns are mean $+\mathrm{SD}$ of values from three donors assayed individually and tested with a one-tailed paired $t$-test $\left({ }^{*} p<0.05,{ }^{* *} p<0.005\right)$.

$\mathrm{CD}^{+} \mathrm{T}$ cells were co-cultured, the naive $\mathrm{CD} 4^{+} \mathrm{T}$ cells even showed a clearly reduced response toward anti-CD3 stimulation (Figures 5C,D) suggesting that also in unseparated PBMC the $\mathrm{CD}^{+} \mathrm{T}$ cell response to anti-CD3 mAb stimulation was mainly due to responding memory cells (Figure 4).

Together, expansion of anti-CD3 mAb stimulated total human $\mathrm{CD}^{+} \mathrm{T}$ cells as well as PPD-specific memory $\mathrm{CD} 4^{+} \mathrm{T}$ cells was enhanced by CD28 costimulation. In contrast, expansion of $\mathrm{Td}$-specific memory $\mathrm{CD} 4^{+} \mathrm{T}$ cells was largely independent of CD28 costimulation.

\section{CD28 Costimulation Favors GATA-3 Over T-Bet Expression in Human Memory $\mathrm{CD4}^{+} \mathrm{T}$ Cells}

Antigenic stimulation of CFSE-labeled human PBMC with PPD or $\mathrm{Td}$ allowed us to identify antigen-reactive memory $\mathrm{CD} 4^{+}$
T cells (Figure 4A). Therefore, we could assess how CD28 costimulation affects T-bet and GATA-3 expression in human memory $\mathrm{CD}^{+} \mathrm{T}$ cells as markers of lineage stability. Under Th0 conditions blockade of CD28-ligand binding increased the T-bet/GATA-3 ratio in Td-specific memory $\mathrm{CD}^{+} \mathrm{T}$ cells (Figures 6A,B-left graph, white columns). The same was true for Td-specific cells stimulated in a Th2 milieu (Figure 6B-right graph, white columns). Pro-inflammatory Th1 polarizing conditions, however, per se induced a higher T-bet/GATA-3 ratio in PPD- and Td-specific memory $\mathrm{CD}^{+} \mathrm{T}$ cells than Th 0 conditions (Figure 6B-middle graph, gray, and white columns), which was not modulated by blockade of CD28 costimulation. In antiCD3 mAb-stimulated CD4 ${ }^{+} \mathrm{T}$ cells inhibition of CD28-ligand binding led to a higher T-bet/Gata3 ratio under Th2 conditions (Figure 6B-black columns). The differentiation status of human, particularly Td-specific, memory $\mathrm{CD}^{+} \mathrm{T}$ cells was, thus, sensitive toward CD28 costimulation, which favored reprogramming 


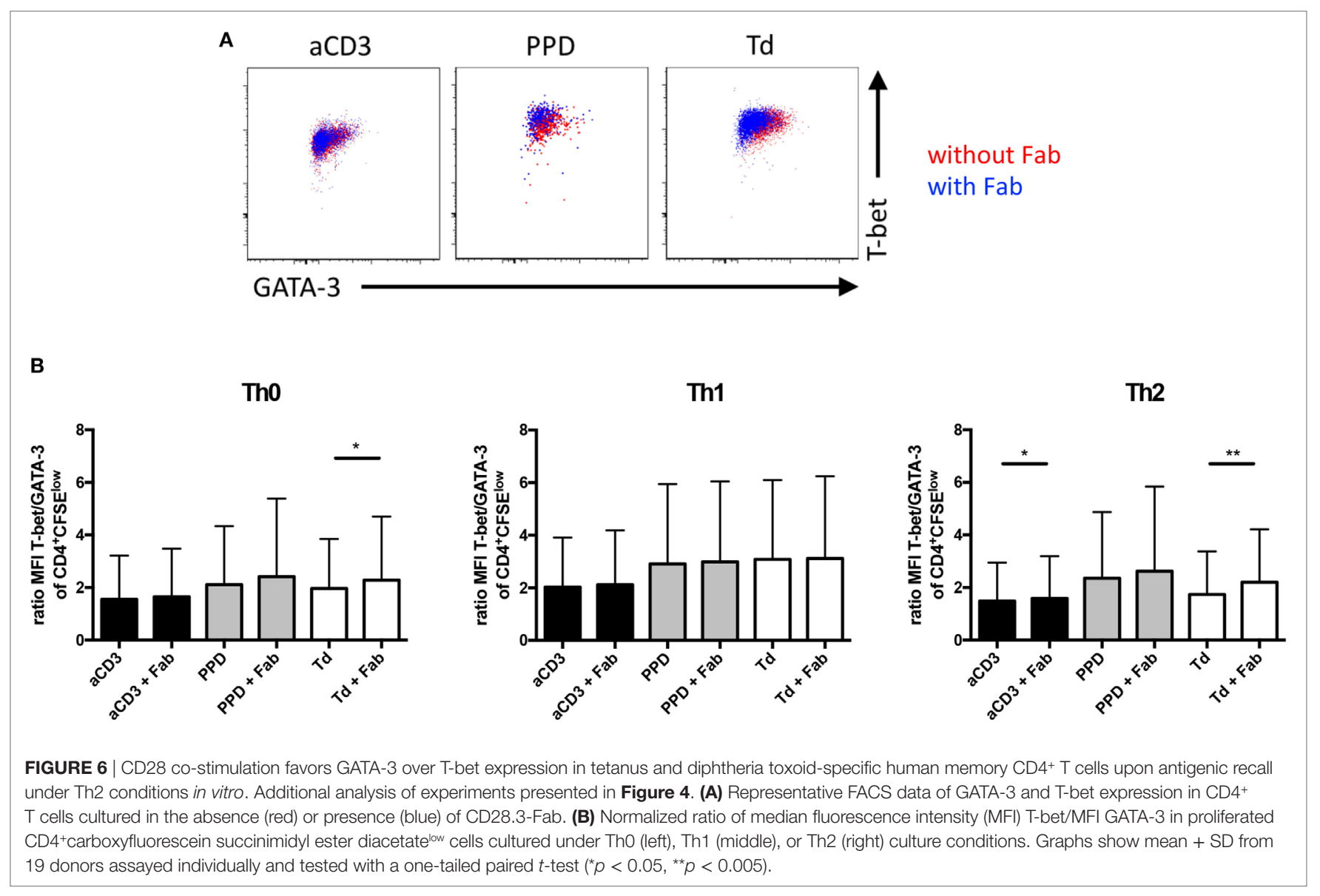

toward a Th2 phenotype characterized by a low ratio of T-bet/ GATA-3 expression.

\section{IFN $\gamma$ and IL-5 Release From Human PBMC Is Enhanced by CD28-Mediated Costimulation}

Challenging mice with antigen in vivo (Figure 1) and culturing mouse Th1 cells in vitro (Figure 3 ) showed that CD28 costimulation enhanced IFN $\gamma$ release from Th1 cells. Therefore, we tested whether CD28 costimulation would also modulate cytokine release from human PBMC stimulated with PPD or Td and, for comparison, anti-CD3 mAb in solution. We observed that IFN $\gamma$ release triggered by anti-CD3 $\mathrm{mAb}, \mathrm{PPD}$, or $\mathrm{Td}$ was enhanced upon CD28 costimulation when the cells were kept under Th0 conditions (Figure 7A, left graph). Shifting the culture conditions to pro-inflammatory Th1 abolished the need for CD28 costimulation to obtain maximum IFN $\gamma$ release (Figure 7A, middle graph). Under Th2 conditions, in which human T cells did not comprise addition of an anti-IFN $\gamma \mathrm{mAb}$, the amounts of IFN $\gamma$ detectable in the supernatants were reduced compared to Th0 and Th1 conditions. Here, CD28 costimulation also did not enhance IFN $\gamma$ release (Figure 7A, right graph). IL-5 secretion was enhanced by CD28-mediated costimulation under Th0 conditions upon stimulation with anti-CD3 mAb or PPD (Figure 7B, left graph). Under Th2 conditions CD28 costimulation increased IL-5 secretion upon addition of PPD or Td (Figure 7B, right graph), while in the Th1 milieu IL- 5 release was enhanced by CD28 costimulation together with anti-CD3 $\mathrm{mAb}$ or Td (Figure $7 \mathbf{B}$, middle graph). CD28 costimulation, thus, enhanced secretion of IFN $\gamma$ and IL-5 from human PBMC upon antigenic recall stimulation.

\section{DISCUSSION}

In this study, we addressed the role of CD28 costimulation for mouse Th1 $\mathrm{T}$ cell function both in vivo and in vitro. Our data identify CD28 costimulation as a key driver of IFN $\gamma$ secretion induced by restimulated Th1 cells in vivo. This positive effect of CD28 costimulation was not restricted to mouse $\mathrm{T}$ cells as cytokine secretion by human PBMC stimulated with $\mathrm{T}$ cell recall antigens in vitro was also enhanced by CD28 costimulation.

We first differentiated OVA-specific OT-II CD4 ${ }^{+} \mathrm{T}$ cells into Th1 cells in vitro before adoptive transfer into fully immunocompetent $\mathrm{C} 57 \mathrm{BL} / 6$ recipient mice. In contrast to many previous studies addressing the role of CD28 costimulation for effector and memory $\mathrm{CD}^{+} \mathrm{T}$ cell function, it was only then that we interfered with CD28 costimulation by specific targeting. We used either Fab fragments of the anti-CD28 mAb E18 blocking ligand binding to CD28 (18) or we genetically deleted CD28 expression in iCD28ko OT-II Th1 cells. This strategy avoids the pitfalls associated with the use of CTLA-4-Ig and with CD28 deletion already during 

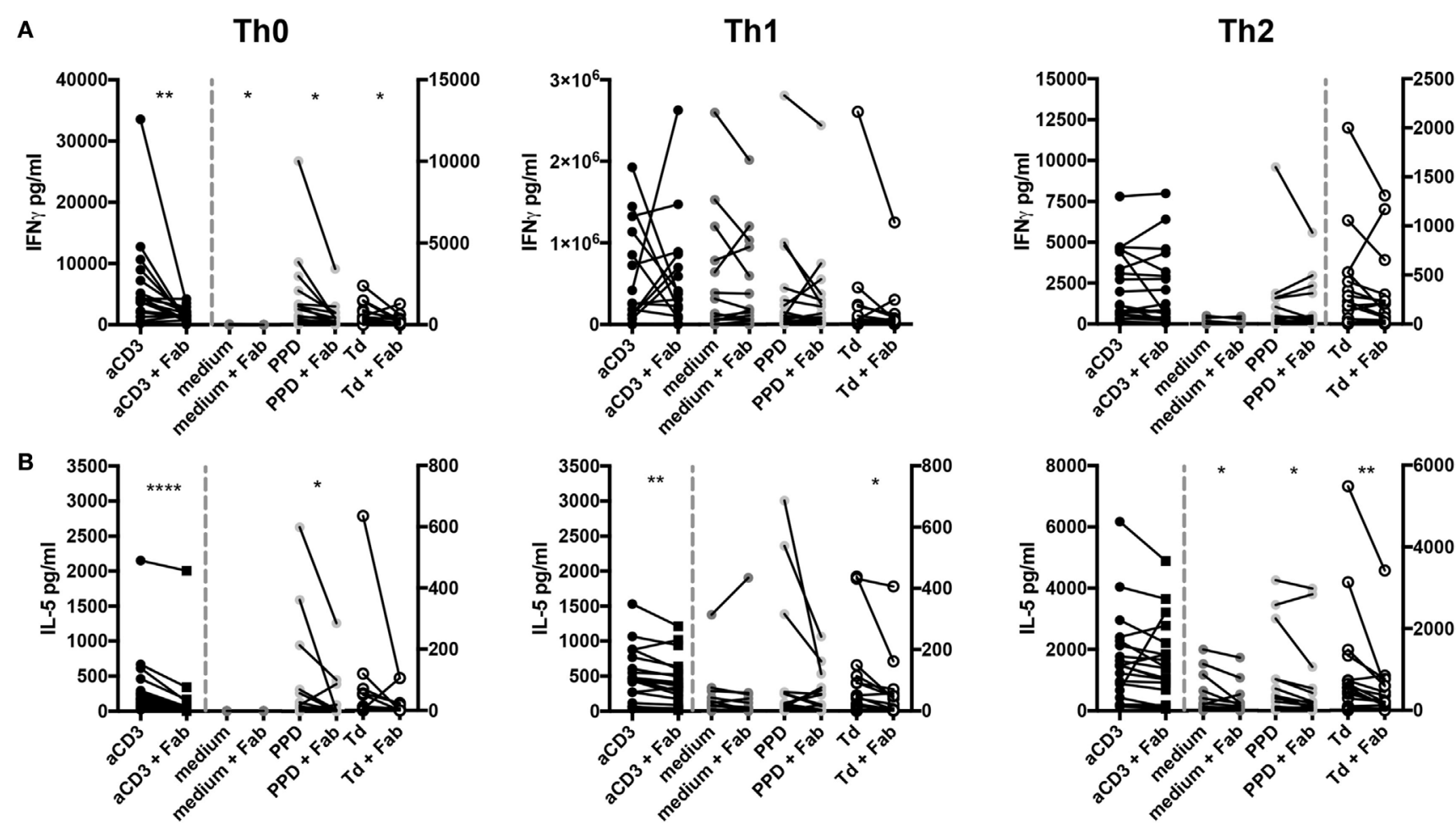

FIGURE 7 | CD28 costimulation enhances cytokine release from peripheral blood mononuclear cells (PBMCs) upon antigenic recall stimulation with purified protein derivative or tetanus and diphtheria toxoid in vitro. (A) Interferon $\gamma(\mathrm{IFN} \gamma)$ and (B) interleukin-5 concentrations in supernatants of experiments are first shown in Figure 4, i.e., under Th0 (left), T helper (Th1) (middle), or Th2 (right) culture conditions. Please note that for human T cells Th1 conditions did not comprise addition of an anti-IFN $\gamma$ antibody as was the case for mouse Th1 conditions. Graphs show data from 19 donors assayed individually and tested with a one-tailed paired $t$-test $\left({ }^{*} p<0.05,{ }^{* *} p<0.005\right)$

initial clonal expansion $(3,6)$. In our study, CD28-deficiency was truly confined to the period of antigenic restimulation in vivo, a situation coming very close to clinical scenarios in humans who generally harbor huge populations of fully differentiated (pathological) T cells by the time patients seek medical attention.

CD28 costimulation had no impact on the secondary expansion of the Th1 cells in vivo (Figures $2 \mathrm{~A}, \mathbf{B}$ ), which is, of course, in contrast to primary responses of naive $\mathrm{CD} 4^{+} \mathrm{T}$ cells (1). We, however, noted that the Th1 cells underwent a certain degree of reprogramming toward a Th2 phenotype in vivo as indicated by reduced frequencies of IFN $\gamma$ producers and a lower ratio of the MFIs for T-bet and Gata-3 in the recovered OT-II T cells (Figure 2 and data not shown). This reprogramming most likely reflects the change in milieu the OT-II T cells experience after transfer from the strongly Th1-polarizing in vitro cultures into healthy $\mathrm{C} 57 \mathrm{BL} / 6$ recipient mice, i.e., into animals without an ongoing immune response.

In contrast to secondary clonal expansion and lineage stability, IFN $\gamma$ release was markedly reduced upon CD28 blockade in vitro (Figure 3) and in vivo (Figure 1C left graph) or after genetic deletion of CD28 on Th1 cells in vivo (Figure 1C right graph). As genetic CD28 deletion only affected CD28 expression by the transferred Th1 OT-II T cells, but not bystander T cells, it was CD28 costimulation of the transferred Th1 cells themselves, which controlled systemic IFN $\gamma$ release. Our in vitro restimulation data further confirmed that IFN $\gamma$ release from Th1 cells was enhanced upon CD28 costimulation (Figure 3B). In vivo, however, we assume that IFN $\gamma$ secretion by bystander memory $\mathrm{CD}^{+} \mathrm{T}$ cells (22), after activation by the transferred Th1 cells, contributed to the total amount of IFN $\gamma$ released into the circulation. This further means that the amount of IFN $\gamma$ released upon costimulation of Th1 cells in vivo should positively correlate with the size of the memory $\mathrm{CD}^{+} \mathrm{T}$ cell compartment in an animal. We would, thus, expect that mice kept under "pet shop-like" conditions with similarly high immunological competence as adult humans (29) would show even stronger CD28-dependent IFN $\gamma$ release upon Th1 cell recall stimulation than the cleanly housed laboratory animals we used in our study. For the release of cytokines from human memory T cells this, in turn, means that the large memory compartment in peripheral blood $\mathrm{T}$ cells should allow to determine the impact of CD28 costimulation on cytokine secretion upon antigenic recall with high sensitivity.

Studying human T cell responses to anti-CD3 mAb stimulation and recall responses to PPD and Td we observed that the CD28.3-Fab reduced the expansion of anti-CD3 $\mathrm{mAb}$ - and PPD-stimulated human $\mathrm{CD} 4^{+} \mathrm{T}$ cells (Figure 4), which is in accordance with previous studies using FR104 to inhibit expansion of alloreactive and viral peptide-specific human $\mathrm{T}$ cells $(10,11)$. Expansion of Td-specific CD $4^{+} \mathrm{T}$ cells was, however, not affected by blocking CD28 signaling (Figure 4). This might be 
due to the polarization of the Td-specific $\mathrm{CD} 4^{+} \mathrm{T}$ cells comprising both Th1 and Th2 cells (24-26), while viral antigen- (30-33) and PPD-specific T cells (27) in healthy subjects are predominantly of a Th1 phenotype. Moreover, memory B cells specific for PPD $(34)$ or $\operatorname{Td}(35,36)$, of course, readily take up antigen and present it to the memory T cells. Therefore, the pool of APCs differs between these bacterial recall antigens studied here and viral peptides loaded onto HLA molecules externally (10). The contribution of CD28 costimulation to secondary expansion of human memory $\mathrm{T}$ cells with different antigenic specificities, thus, varies, which is probably due to the composition of the different memory $\mathrm{T}$ cell pools (Th1/Th2) and to the type of cell presenting the antigen.

CD28 costimulation shifted Td-specific memory $\mathrm{T}$ cells toward a Th2 phenotype with regards to GATA-3 and T-bet expression (Figure 6). CD28 costimulation, thus, appears to not only favor GATA-3 over T-bet expression in naive (mouse) CD4 ${ }^{+}$ $\mathrm{T}$ cells (37), but also in human memory $\mathrm{T}$ cells. In naive $\mathrm{CD} 4^{+}$ T cells CD28 costimulation has been shown to enhance (38-41) and, under certain conditions, to be even sufficient to induce Th2 differentiation (42). In contrast, CD28 costimulation of mouse memory $\mathrm{CD}^{+} \mathrm{T}$ cells in vivo (Figure 1) and human memory $\mathrm{CD}^{+} \mathrm{T}$ cells in vitro (Figure 7 ) did not actually reprogram the cells toward a Th2 phenotype marked by high IL-4 or IL- 5 and low IFN $\gamma$ secretion. A lower T-bet/GATA-3 ratio may, however, have an impact on $\mathrm{T}$ cell migration given the distinctive expression of chemokine receptors on human Th1 and Th2 T cells $(43,44)$, which we did not study here, but which could, of course, substantially contribute to modulation of memory $\mathrm{T}$ cell responses in vivo. The reason we did not include chemokine receptor expression as a means to define human Th cell subsets in our study was that Ficoll density centrifugation of the cells obtained from the LRS-C led to a very high degree of internalization of chemokine receptors (45) so that these were undetectable on the cell surface by flow cytometry (data not shown). Also in line with published work (45) activation of the $\mathrm{T}$ cells in vitro did not induce re-expression of the receptors, i.e., after 6 days of culture there was no differential expression of chemokine receptors on the cultured T cells (data not shown).

A key result of our experiments with human PBMC was that CD28 costimulation substantially enhanced IFN $\gamma$ secretion after stimulation with anti-CD3 mAb, PPD, or Td (Figure 7). Control of cytokine release was, however, not restricted to IFN $\gamma$ as IL-5 secretion upon PPD stimulation under Th0 conditions and upon PPD or Td stimulation under Th2 conditions was also markedly reduced upon CD28 inhibition (Figure 7) - as was the case for mouse OT-II Th1 cells cultured under Th2 conditions (Figure 3C).

Molecularly, we assume that induction of glycolysis and increasing mitochondrial respiratory capacity by CD28 costimulation $(20,46)$ in the memory $\mathrm{T}$ cells enhances both IFN $\gamma$ (19) and IL-5 as well as GATA-3 expression (47). IFN $\gamma$ production by Th1 cells relies on GAPDH being recruited to glycolytic processes thus liberating $\operatorname{IFN} \gamma \operatorname{mRNA}(19,48)$. Regarding proliferation, $\mathrm{CD}^{+} \mathrm{T}$ cells may cover their energy supply either by glycolysis or oxidative phosphorylation (19). These two observations together could explain why secondary expansion of the OT-II Th1 cells in vivo was not impaired in the absence of CD28 costimulation (Figure 1), while systemic IFN $\gamma$ release was reduced (Figure 1). Moreover, the reduced dependence of $\mathrm{CD}^{+} \mathrm{T}$ cells, compared to $\mathrm{CD} 8^{+} \mathrm{T}$ cells, on glycolysis for activation-induced expansion $(49,50)$ also explains why memory $\mathrm{CD}^{+} \mathrm{T}$ cells depend more strongly on CD28 costimulation for optimal expansion upon antigenic recall in vivo (51) than $\mathrm{CD} 4^{+} \mathrm{T}$ cells.

Finally, our observation that CD28 costimulation plays a key role in $\mathrm{CD}^{+} \mathrm{T}$ cell recall responses also provides further explanations as to why it is biologically reasonable to target the CD28 pathway by the inhibitory receptors CTLA-4 (52) and PD-1 $(53,54)$ which themselves are only expressed after $\mathrm{T}$ cell activation. Upon therapeutic blockade of PD-1 on $\mathrm{CD}^{+} \mathrm{T}$ cells it has been shown that CD28 signaling is liberated allowing for full memory $\mathrm{T}$ cell responses to occur (54). Moreover, our data suggest that in situations of continued auto-aggression by memory $\mathrm{CD}^{+}$, and probably also $\mathrm{CD}^{+}$, $\mathrm{T}$ cells, therapeutic inhibition of CD28 costimulation might be efficacious. This is, for example, the case in patients suffering from multiple sclerosis who harbor myelin-reactive Th1 cells (55). Further, blocking CD28 ligation may also facilitate actual reprogramming of pathogenic Th1 cells toward, e.g., a Th2 phenotype. Reprogramming of both mouse (8) and human CD4 ${ }^{+}$Th cells (7) requires TCR stimulation and an appropriate cytokine milieu. TCR ligation, however, comes with the risk of inducing an (initial) flare of the disease (55), which, according to our data, might be avoided by concomitant inhibition of CD28 ligation by co-treatment of patients with the anti-CD28 Fab' antibody fragment FR104 $(10,11)$.

\section{ETHICS STATEMENT}

All animal experiments were performed in accordance with German law and approved by the Regierung von Unterfranken as the responsible authority. The ethics committee of the medical faculty of the University of Würzburg approved the anonymous use of human PBMC from healthy blood donors for this study.

\section{AUTHOR CONTRIBUTIONS}

DL and NB designed the experiments. DL, SH, SG, AU, FL, BV, and $\mathrm{TH}$ contributed to performing and analyzing the experiments and interpreting the results. NB directed the study and wrote the manuscript, with input from $\mathrm{DL}, \mathrm{SH}$, and $\mathrm{TH}$.

\section{ACKNOWLEDGMENTS}

We would like to thank the Core Unit for Confocal Microscopy and Flow Cytometry-based Cell Sorting of the IZKF Würzburg for supporting this study.

\section{FUNDING}

This study was funded by grants from the Deutsche Forschungsgemeinschaft (BE 4080/2-1 and $\mathrm{Hu} 295 / 12-1$ ) and by the University of Würzburg in the funding program Open Access Publishing. 


\section{REFERENCES}

1. Chen L, Flies DB. Molecular mechanisms of T cell co-stimulation and coinhibition. Nat Rev Immunol (2013) 13(4):227-42. doi:10.1038/nri3405

2. Boesteanu AC, Katsikis PD. Memory T cells need CD28 costimulation to remember. Semin Immunol (2009) 21(2):69-77. doi:10.1016/j.smim.2009. 02.005

3. Ndejembi MP, Teijaro JR, Patke DS, Bingaman AW, Chandok MR, Azimzadeh A, et al. Control of memory CD4 T cell recall by the CD28/B7 costimulatory pathway. J Immunol (2006) 177(11):7698-706. doi:10.4049/ jimmunol.177.11.7698

4. Krummel MF, Allison JP. CD28 and CTLA-4 have opposing effects on the response of T cells to stimulation. J Exp Med (1995) 182(2):459-65. doi:10.1084/jem.182.2.459

5. Grohmann U, Orabona C, Fallarino F, Vacca C, Calcinaro F, Falorni A, et al. CTLA-4-Ig regulates tryptophan catabolism in vivo. Nat Immunol (2002) 3(11):1097-101. doi:10.1038/ni846

6. Linterman MA, Denton AE, Divekar DP, Zvetkova I, Kane L, Ferreira C, et al. CD28 expression is required after T cell priming for helper $\mathrm{T}$ cell responses and protective immunity to infection. Elife (2014) 3. doi:10.7554/eLife.03180

7. Messi M, Giacchetto I, Nagata K, Lanzavecchia A, Natoli G, Sallusto F. Memory and flexibility of cytokine gene expression as separable properties of human T(H)1 and T(H)2 lymphocytes. Nat Immunol (2003) 4(1):78-86. doi:10.1038/ni872

8. Hegazy AN, Peine M, Helmstetter C, Panse I, Frohlich A, Bergthaler A, et al. Interferons direct Th2 cell reprogramming to generate a stable GATA-3(+) T-bet(+) cell subset with combined Th2 and Th1 cell functions. Immunity (2010) 32(1):116-28. doi:10.1016/j.immuni.2009.12.004

9. Panzer M, Sitte S, Wirth S, Drexler I, Sparwasser T, Voehringer D. Rapid in vivo conversion of effector T cells into Th2 cells during helminth infection. J Immunol (2012) 188(2):615-23. doi:10.4049/jimmunol.1101164

10. Poirier N, Chevalier M, Mary C, Hervouet J, Minault D, Baker P, et al. Selective CD28 antagonist blunts memory immune responses and promotes long-term control of skin inflammation in nonhuman primates. J Immunol (2016) 196(1):274-83. doi:10.4049/jimmunol.1501810

11. Dillinger B, Ahmadi-Erber S, Soukup K, Halfmann A, Schrom S, Vanhove B, et al. CD28 blockade ex vivo induces alloantigen-specific immune tolerance but preserves T-cell pathogen reactivity. Front Immunol (2017) 8:1152. doi:10.3389/fimmu.2017.01152

12. Snell GD, Cherry M. Loci determining cell surface antigens. In: Emmelot P, Bentvelsen P, editors. RNA Viruses and Host Genome in Oncogenesis. Amsterdam: North Holland (1972). p. 221-8.

13. Barnden MJ, Allison J, Heath WR, Carbone FR. Defective TCR expression in transgenic mice constructed using cDNA-based alpha- and beta-chain genes under the control of heterologous regulatory elements. Immunol Cell Biol (1998) 76(1):34-40. doi:10.1046/j.1440-1711.1998.00709.x

14. Gogishvili T, Luhder F, Kirstein F, Nieuwenhuizen NE, Goebbels S, Beer-Hammer S, et al. Interruption of CD28-mediated costimulation during allergen challenge protects mice from allergic airway disease. J Allergy Clin Immunol (2012) 130(6):1394-403.e4. doi:10.1016/j.jaci.2012.08.049

15. Gogishvili T, Luhder F, Goebbels S, Beer-Hammer S, Pfeffer K, Hunig T. Cell-intrinsic and -extrinsic control of Treg-cell homeostasis and function revealed by induced CD28 deletion. Eur J Immunol (2013) 43(1):188-93. doi:10.1002/eji.201242824

16. Dietz AB, Bulur PA, Emery RL, Winters JL, Epps DE, Zubair AC, et al. A novel source of viable peripheral blood mononuclear cells from leukoreduction system chambers. Transfusion (2006) 46(12):2083-9. doi:10.1111/ j.1537-2995.2006.01033.x

17. Dennehy KM, Elias F, Zeder-Lutz G, Ding X, Altschuh D, Luhder F, et al. Cutting edge: monovalency of CD28 maintains the antigen dependence of $\mathrm{T}$ cell costimulatory responses. J Immunol (2006) 176(10):5725-9. doi:10.4049/jimmunol.176.10.5725

18. Beyersdorf N, Ding X, Blank G, Dennehy KM, Kerkau T, Hunig T. Protection from graft-versus-host disease with a novel B7 binding site-specific mouse anti-mouse CD28 monoclonal antibody. Blood (2008) 112(10):4328-36. doi:10.1182/blood-2008-03-146662

19. Chang CH, Curtis JD, Maggi LB Jr, Faubert B, Villarino AV, O’Sullivan D, et al. Posttranscriptional control of $\mathrm{T}$ cell effector function by aerobic glycolysis. Cell (2013) 153(6):1239-51. doi:10.1016/j.cell.2013.05.016
20. Frauwirth KA, Riley JL, Harris MH, Parry RV, Rathmell JC, Plas DR, et al. The CD28 signaling pathway regulates glucose metabolism. Immunity (2002) 16(6):769-77. doi:10.1016/S1074-7613(02)00323-0

21. Patke DS, Farber DL. Modulation of memory CD4 T cell function and survival potential by altering the strength of the recall stimulus. J Immunol (2005) 174(9):5433-43. doi:10.4049/jimmunol.174.9.5433

22. Lertmemongkolchai G, Cai G, Hunter CA, Bancroft GJ. Bystander activation of CD8+ T cells contributes to the rapid production of IFN-gamma in response to bacterial pathogens. J Immunol (2001) 166(2):1097-105. doi:10.4049/ jimmunol.166.2.1097

23. Yu XZ, Albert MH, Martin PJ, Anasetti C. CD28 ligation induces transplantation tolerance by IFN-gamma-dependent depletion of $\mathrm{T}$ cells that recognize alloantigens. J Clin Invest (2004) 113(11):1624-30. doi:10.1172/ JCI20940

24. Rowe J, Macaubas C, Monger TM, Holt BJ, Harvey J, Poolman JT, et al. Antigen-specific responses to diphtheria-tetanus-acellular pertussis vaccine in human infants are initially Th2 polarized. Infect Immun (2000) 68(7):3873-7. doi:10.1128/IAI.68.7.3873-3877.2000

25. Kolata JB, Kuhbandner I, Link C, Normann N, Vu CH, Steil L, et al. The fall of a dogma? Unexpected high T-cell memory response to Staphylococcus aureus in humans. J Infect Dis (2015) 212(5):830-8. doi:10.1093/infdis/jiv128

26. Vu CH, Kolata J, Stentzel S, Beyer A, Gesell Salazar M, Steil L, et al. Adaptive immune response to lipoproteins of Staphylococcus aureus in healthy subjects. Proteomics (2016) 16(20):2667-77. doi:10.1002/pmic.201600151

27. Marchant A, Amedei A, Azzurri A, Vekemans J, Benagiano M, Tamburini C, et al. Polarization of PPD-specific T-cell response of patients with tuberculosis from Th0 to Th1 profile after successful antimycobacterial therapy or in vitro conditioning with interferon-alpha or interleukin-12. Am J Respir Cell Mol Biol (2001) 24(2):187-94. doi:10.1165/ajrcmb.24.2.4274

28. Nunes J, Klasen S, Ragueneau M, Pavon C, Couez D, Mawas C, et al. CD28 $\mathrm{mAbs}$ with distinct binding properties differ in their ability to induce $\mathrm{T}$ cell activation: analysis of early and late activation events. Int Immunol (1993) 5(3):311-5. doi:10.1093/intimm/5.3.311

29. Beura LK, Hamilton SE, Bi K, Schenkel JM, Odumade OA, Casey KA, et al. Normalizing the environment recapitulates adult human immune traits in laboratory mice. Nature (2016) 532(7600):512-6. doi:10.1038/nature17655

30. Waldrop SL, Pitcher CJ, Peterson DM, Maino VC, Picker LJ. Determination of antigen-specific memory/effector CD4+ $\mathrm{T}$ cell frequencies by flow cytometry: evidence for a novel, antigen-specific homeostatic mechanism in HIV-associated immunodeficiency. J Clin Invest (1997) 99(7):1739-50. doi:10.1172/JCI119338

31. Munz C, Bickham KL, Subklewe M, Tsang ML, Chahroudi A, Kurilla MG, et al. Human CD4(+) T lymphocytes consistently respond to the latent EpsteinBarr virus nuclear antigen EBNA1. J Exp Med (2000) 191(10):1649-60. doi:10.1084/jem.191.10.1649

32. Casazza JP, Betts MR, Price DA, Precopio ML, Ruff LE, Brenchley JM, et al. Acquisition of direct antiviral effector functions by CMV-specific CD4+ T lymphocytes with cellular maturation. J Exp Med (2006) 203(13):2865-77. doi:10.1084/jem.20052246

33. Lee LY, Ha do LA, Simmons C, de Jong MD, Chau NV, Schumacher R, et al. Memory $\mathrm{T}$ cells established by seasonal human influenza A infection crossreact with avian influenza A ( $\mathrm{H} 5 \mathrm{~N} 1)$ in healthy individuals. J Clin Invest (2008) 118(10):3478-90. doi:10.1172/JCI32460

34. Sebina I, Cliff JM, Smith SG, Nogaro S, Webb EL, Riley EM, et al. Long-lived memory B-cell responses following BCG vaccination. PLoS One (2012) 7(12):e51381. doi:10.1371/journal.pone.0051381

35. Odendahl M, Mei H, Hoyer BF, Jacobi AM, Hansen A, Muehlinghaus G, et al. Generation of migratory antigen-specific plasma blasts and mobilization of resident plasma cells in a secondary immune response. Blood (2005) 105(4):1614-21. doi:10.1182/blood-2004-07-2507

36. Blanchard Rohner G, Snape MD, Kelly DF, John T, Morant A, Yu LM, et al. The magnitude of the antibody and memory B cell responses during priming with a protein-polysaccharide conjugate vaccine in human infants is associated with the persistence of antibody and the intensity of booster response. J Immunol (2008) 180(4):2165-73. doi:10.4049/jimmunol.180.4.2165

37. Bian Y, Hiraoka S, Tomura M, Zhou XY, Yashiro-Ohtani Y, Mori Y, et al. The capacity of the natural ligands for CD28 to drive IL-4 expression in naive and antigen-primed CD4+ and CD8+ T cells. Int Immunol (2005) 17(1):73-83. doi:10.1093/intimm/dxh188 
38. Corry DB, Reiner SL, Linsley PS, Locksley RM. Differential effects of blockade of CD28-B7 on the development of Th1 or Th2 effector cells in experimental leishmaniasis. J Immunol (1994) 153(9):4142-8.

39. Lenschow DJ, Herold KC, Rhee L, Patel B, Koons A, Qin HY, et al. CD28/ B7 regulation of Th1 and Th2 subsets in the development of autoimmune diabetes. Immunity (1996) 5(3):285-93. doi:10.1016/S1074-7613(00)80323-4

40. Rulifson IC, Sperling AI, Fields PE, Fitch FW, Bluestone JA. CD28 costimulation promotes the production of Th2 cytokines. J Immunol (1997) 158(2):658-65.

41. Rudulier CD, McKinstry KK, Al-Yassin GA, Kroeger DR, Bretscher PA. The number of responding CD4 T cells and the dose of antigen conjointly determine the TH1/TH2 phenotype by modulating B7/CD28 interactions. J Immunol (2014) 192(11):5140-50. doi:10.4049/jimmunol.1301691

42. Rodriguez-Palmero M, Hara T, Thumbs A, Hunig T. Triggering of T cell proliferation through CD28 induces GATA-3 and promotes T helper type 2 differentiation in vitro and in vivo. Eur J Immunol (1999) 29(12):3914-24. doi:10.1002/ (SICI)1521-4141(199912)29:12<3914::AID-IMMU3914>3.0.CO;2-\#

43. Acosta-Rodriguez EV, Rivino L, Geginat J, Jarrossay D, Gattorno M, Lanzavecchia A, et al. Surface phenotype and antigenic specificity of human interleukin 17-producing T helper memory cells. Nat Immunol (2007) 8(6):639-46. doi:10.1038/ni1467

44. Becattini S, Latorre D, Mele F, Foglierini M, De Gregorio C, Cassotta A, et al. T cell immunity. Functional heterogeneity of human memory CD4(+) T cell clones primed by pathogens or vaccines. Science (2015) 347(6220):400-6. doi:10.1126/science.1260668

45. Nieto JC, Canto E, Zamora C, Ortiz MA, Juarez C, Vidal S. Selective loss of chemokine receptor expression on leukocytes after cell isolation. PLoS One (2012) 7(3):e31297. doi:10.1371/journal.pone.0031297

46. Klein Geltink RI, O'Sullivan D, Corrado M, Bremser A, Buck MD, Buescher JM, et al. Mitochondrial priming by CD28. Cell (2017) 171(2):385-97.e11. doi:10.1016/j.cell.2017.08.018

47. Yang JQ, Kalim KW, Li Y, Zhang S, Hinge A, Filippi MD, et al. RhoA orchestrates glycolysis for $\mathrm{TH} 2$ cell differentiation and allergic airway inflammation. J Allergy Clin Immunol (2016) 137(1):231-45.e4. doi:10.1016/j. jaci.2015.05.004

48. Palmer CS, Ostrowski M, Balderson B, Christian N, Crowe SM. Glucose metabolism regulates $\mathrm{T}$ cell activation, differentiation, and functions. Front Immunol (2015) 6:1. doi:10.3389/fimmu.2015.00001
49. Wahl DR, Byersdorfer CA, Ferrara JL, Opipari AW Jr, Glick GD. Distinct metabolic programs in activated T cells: opportunities for selective immunomodulation. Immunol Rev (2012) 249(1):104-15. doi:10.1111/j.1600-065X. 2012.01148.x

50. Cao Y, Rathmell JC, Macintyre AN. Metabolic reprogramming towards aerobic glycolysis correlates with greater proliferative ability and resistance to metabolic inhibition in CD8 versus CD4 T cells. PLoS One (2014) 9(8):e104104. doi:10.1371/journal.pone.0104104

51. Frohlich M, Gogishvili T, Langenhorst D, Luhder F, Hunig T. Interrupting CD28 costimulation before antigen rechallenge affects CD8(+) T-cell expansion and effector functions during secondary response in mice. Eur J Immunol (2016) 46(7):1644-55. doi:10.1002/eji.201546232

52. Beyersdorf N, Kerkau T, Hunig T. CD28 co-stimulation in T-cell homeostasis: a recent perspective. Immunotargets Ther (2015) 4:111-22. doi:10.2147/ITT. S61647

53. Hui E, Cheung J, Zhu J, Su X, Taylor MJ, Wallweber HA, et al. T cell costimulatory receptor CD28 is a primary target for PD-1-mediated inhibition. Science (2017) 355(6332):1428-33. doi:10.1126/science.aaf1292

54. Kamphorst AO, Wieland A, Nasti T, Yang S, Zhang R, Barber DL, et al. Rescue of exhausted CD8 T cells by PD-1-targeted therapies is CD28-dependent. Science (2017) 355(6332):1423-7. doi:10.1126/science.aaf0683

55. Bielekova B, Goodwin B, Richert N, Cortese I, Kondo T, Afshar G, et al. Encephalitogenic potential of the myelin basic protein peptide (amino acids 83-99) in multiple sclerosis: results of a phase II clinical trial with an altered peptide ligand. Nat Med (2000) 6(10):1167-75. doi:10.1038/80516

Conflict of Interest Statement: BV is chief operating officer and shareholder of OSE immunotherapeutics. All other authors have declared that no conflict of interest exists.

Copyright (c) 2018 Langenhorst, Haack, Göb, Uri, Lühder, Vanhove, Hünig and Beyersdorf. This is an open-access article distributed under the terms of the Creative Commons Attribution License (CC BY). The use, distribution or reproduction in other forums is permitted, provided the original author(s) and the copyright owner are credited and that the original publication in this journal is cited, in accordance with accepted academic practice. No use, distribution or reproduction is permitted which does not comply with these terms. 